\title{
Expression and biological activity of two recombinant polypeptides related to subunit 1 of the interferon- $\alpha$ receptor
}

\section{S. Yoon ${ }^{1}$, R.D.C. Hirata ${ }^{1}$ N.Y. N guyen², R. Curi ${ }^{3}$, $M$. Russo 4 and M.H. Hirata ${ }^{1}$}

\author{
${ }^{1}$ Departamento de Análises Clínicas e Toxicológicas, Faculdade de Ciências \\ Farmacêuticas, Universidade de São Paulo, São Paulo, SP, Brasil \\ ${ }^{2}$ Facility for Biotechnology Resources, Center for Biologics Evaluation and Research, \\ Food and Drug Administration, Bethesda, MD, USA \\ Departamentos de ${ }^{3}$ Fisiologia e Biofísica, and ${ }^{4}$ mmunologia, \\ Instituto de Ciências Biomédicas, Universidade de São Paulo, São Paulo, SP, Brasil
}

\section{Correspondence \\ S. Yoon \\ Departamento de Análises Clínicas e Toxicológicas, FCF, USP \\ Av. Lineu Prestes, 580, Bloco 17 05508-900 São Paulo, SP Brasil \\ Fax: +55-11-813-2197 \\ E-mail: sunok@zipmail.com.br \\ Research supported by CAPES and FAPESP.}

Received April 28, 1999

Accepted March 22, 2000

\section{Abstract}

Abnormal production of interferon alpha (IFN- $\alpha$ ) has been found in certain autoimmune diseases and can be also observed after prolonged therapy with IFN- $\alpha$. IFN- $\alpha$ can contribute to the pathogenesis of allograft rejection in bone marrow transplants. Therefore, the development of IFN- $\alpha$ inhibitors as a soluble receptor protein may be valuable for the therapeutic control of these diseases. We have expressed two polypeptides encoding amino acids 93-260 (P1) and 261410 (P2) of the extracellular domain of subunit 1 of the interferon- $\alpha$ receptor (IFNAR 1-EC) in E. coli. The activities of the recombinant polypeptides and of their respective antibodies were evaluated using antiproliferative and antiviral assays. Expression of P1 and P2 polypeptides was achieved by transformation of cloned plasmid pRSET A into E. coli BL21(DE3)pLysS and by IPTG induction. P1 and P2 were purified by serial sonication steps and by gel filtration chromatography with $8 \mathrm{M}$ urea and refolded by dialysis. Under reducing SDSPAGE conditions, the molecular weight of P1 and P2 was 22 and 17 $\mathrm{kDa}$, respectively. Polyclonal anti-P1 and anti-P2 antibodies were produced in mice. P1 and P2 and their respective polyclonal antibodies were able to block the antiproliferative activity of $6.25 \mathrm{nM}$ IFN- $\alpha \mathrm{B}$ on Daudi cells, but did not block IFN- $\alpha$ B activity at higher concentrations $(>6.25 \mathrm{nM})$. On the other hand, the polypeptides and their respective antibodies did not inhibit the antiviral activity of IFN- $\alpha B$ on Hep 2/c cells challenged with encephalomyocarditis virus.

\section{Key words}

- Interferon alpha

- Interferon- $\alpha$ receptor

- Inhibitor of interferon- $\alpha$

- Autoimmune diseases

- Graft-versus-host disease

- Recombinant protein

\section{Introduction}

Interferons (IFNs) are biologically active proteins produced by cells in response to a variety of stimuli such as microbes, tumors and antigens. IFNs exert antiviral, antimicrobial, antitumor, and immunomodulatory ef- fects. These effects are mediated by the binding of IFN to specific receptors on the cell surface, signaling transduction through the nucleus and activating specific genes (1-3). IFNs are assigned to two classes, type I and type II IFN, according to their interaction with specific receptors (4-7). IFNs $\alpha, \beta$ and 
$\omega$ share a common receptor called IFN- $\alpha$ receptor (IFNAR), while IFN- $\gamma$ interacts with a distinct receptor (IFN- $\gamma$ receptor). IFN- $\alpha$ comprises at least 13 subclasses of structurally similar glycoproteins encoded by related genes, whereas IFNs- $\beta,-\gamma$ and $-\omega$ have only 1 subclass (3). Abnormal production of IFN- $\alpha$ has been reported in systemic lupus erythematosus (SLE), type I diabetes and in graft-versus-host disease (GVHD) (8-10). Preble et al. (8) have shown that an acidlabile type of IFN- $\alpha$ is specifically elevated in about $50 \%$ of SLE patients. Increased levels of IFN- $\alpha$ were observed in the pancreases of patients with type I diabetes, while other cytokines (TNF- $\alpha$, IL-1 $\beta$, IL-2, IL-4, and IL-6) were not increased (9). The development of autoimmune diseases and severe GVHD complication has been reported to occur after IFN- $\alpha$ therapy in patients with carcinoid tumors or chronic hepatitis C (1014). It was shown that irradiated mice undergoing GVHD after allogeneic bone marrow transplant develop high levels of IFN- $\alpha$ activity. In contrast, mice given T-cell-depleted allogeneic bone marrow failed to develop GVHD and had no detectable serum IFN- $\alpha$ activity (15). This evidence indicates that IFN- $\alpha$ may contribute to the pathogenesis of autoimmune diseases and plays an important role in allograft rejection of bone marrow transplants (16-18). Therefore, the development of agents antagonistic to IFN- $\alpha$ would greatly contribute to new alternatives for the trreatment of these patients. Indeed, injection of polyclonal anti-mouse IFN- $\alpha / \beta$ antibodies has reduced the resistance to allogeneic bone marrow transplantation in mice, demonstrating their potential inhibition of IFN- $\alpha$ activity in vivo. However, anti-IFN- $\alpha$ antibodies were able to neutralize only some subclasses of IFN- $\alpha$. One approach to the inhibition of the action of IFN- $\alpha$ would be the production of anti-IFNAR antibodies that can block the effects of all IFN- $\alpha$ subclasses. Uzé et al. (19) showed that polyclonal antibodies raised against cells expressing the subunit 1 of IFNAR (IFNAR 1) can neutralize the activity of several IFN- $\alpha$ subclasses. Similarly, Benoit et al. (20) observed that monoclonal antibodies directed against the extracellular domain of the IFNAR, which was expressed in Escherichia coli and COS 7 cells, neutralize the biological activity of rIFN- $\alpha 2, r I F N-\alpha B$, rIFN- $\beta$ and rIFN- $\omega$ and of IFN- $\alpha$ purified from leukocytes or Namalwa cells, as well as the IFN present in the serum of AIDS patients. Nguyen et al. (21) have also expressed the extracellular domain of the IFNAR 1 in Escherichia coli as a fusion protein with glutathione-S-transferase and have demonstrated that this recombinant protein inhibits the antiviral and antiproliferative activities of rIFN- $\alpha \mathrm{B}$ and competes with the cell surface receptor for IFN- $\alpha$ binding. This information led us to search for inhibitors of IFN- $\alpha$ activity by producing polypeptide fragments of IFNAR 1 and raising antibodies to the fragments.

We report here the production of two polypeptide fragments encoding amino acids 93-260 (P1) and 261-410 (P2) of the extracellular domain of IFNAR 1 expressed in Escherichia coli. The biological activity of these polypeptides and of their respective antibodies was evaluated using antiproliferative and antiviral assays.

\section{Material and Methods}

\section{Cell lines}

Human Daudi lymphoblastoid cells were provided by Dr. Kath C. Zoon (Food and Drug Administration, Bethesda, MD, USA) and maintained in RPMI 1640 medium (Gibco) supplemented with 10\% heat-inactivated fetal bovine serum (FBS). Hep $2 / \mathrm{c}$ cells of the epidermoid carcinoma cell line were provided by Dr. Consuelo L.F. Dias (Fundação Ezequiel Dias, Belo Horizonte, MG, Brazil) and maintained in RPMI 1640 medium supplemented with 5\% heatinactivated FBS. 
Interferon

Recombinant IFN- $\alpha \mathrm{B}$, with a specific activity of $2 \times 10^{8} \mathrm{IU} / \mathrm{mg}$, was provided by Dr. David Gangemi (Clemenson State University, SC, USA).

\section{Expression}

The two cDNA fragments of IFNAR 1 encoding insert 1 from nucleotides 277 to 780 and insert 2 from nucleotides 781 to 1230 were produced by the polymerase chain reaction using cDNA of IFNAR 1 as template. Specific oligonucleotide primers containing the restriction enzyme sites EcoRI and BamHI for P1 and EcoRI and NdeI for $\mathrm{P} 2$ were used. cDNA fragments were inserted into plasmid pRSET A (Invitrogen, San Diego, CA, USA) and the clones were sequenced with a Sequenase ${ }^{\mathrm{TM}}$ v2.0 instrument (Amersham, Buckinghamshire, England) (22). Expression of the two fragments of IFNAR 1 cDNA was achieved by transformation into $E$. coli $\mathrm{BL} 21(\mathrm{DE} 3) \mathrm{pLysS}$ cells, followed by IPTG induction for $3 \mathrm{~h}$ at $37^{\circ} \mathrm{C}$ in L-broth containing $100 \mu \mathrm{g} / \mathrm{ml}$ ampicillin and $25 \mu \mathrm{g} / \mathrm{ml}$ chloramphenicol. Polypeptide 1 was synthesized with a polyhistidine linker and an enterokinase cleavage site.

\section{Purification}

Polypeptides $\mathrm{P} 1$ and $\mathrm{P} 2$ produced in $E$. coli as insoluble inclusion bodies were extracted twice by sonication (30 s), using sonication buffer (1 mM EDTA, $100 \mathrm{mM}$ $\mathrm{NaCl}, 1 \mathrm{mM}$ PMSF, $2 \mathrm{mM}$ DTT, and 100 $\mathrm{mM}$ Tris- $\mathrm{HCl}, \mathrm{pH} 9.2$, for $\mathrm{P} 1$ and $\mathrm{pH} 7.5$ for P2) and once more with sonication buffer plus $1 \%$ Triton $\mathrm{X}-100$. The final fraction was solubilized in $8 \mathrm{M}$ urea containing $1 \mathrm{mM}$ DTT, $1 \mathrm{mM}$ EDTA and $100 \mathrm{mM}$ Tris- $\mathrm{HCl}$, $\mathrm{pH}$ 9.2, for P1 and $\mathrm{pH} 7.5$ for P2. The ureasolubilized fractions containing polypeptides $\mathrm{P} 1$ or $\mathrm{P} 2$ were purified by gel filtration chromatography using Sephadex G-100 and G-
50 for P1 and P2, respectively. The purified polypeptides were refolded by dialysis against decreasing concentrations of urea $(6,4,2$, $1.5,1$, and $0 \mathrm{M}$ ) and against RPMI 1640 medium supplemented with $1 \% \mathrm{FBS}$ at $4^{\circ} \mathrm{C}$. The protein content of the purified fractions was determined by Lowry's method (23).

\section{Preparation of polyclonal anti-P1 and anti-P2 antibodies}

Mice were immunized by sc injection with $200 \mu \mathrm{g}$ of polypeptides P1 or P2 in complete Freund adjuvant. After 15 days, incomplete Freund adjuvant was also injected $s c$. Ten days later, the level of specific serum antibodies was assayed by ELISA and the good responders were boosted with polypeptides by $s c$ injection in incomplete Freund adjuvant. Five days later, the serum of the animals was obtained and used as polyclonal antibody after $\operatorname{IgG}$ purification through a protein A column.

\section{In vitro inhibition assay of antiproliferative activity of IFN- $\alpha$ B}

Antiproliferative assays were performed using Daudi cells. Daudi cells were collected by centrifugation and resuspended in warmed $\left(37^{\circ} \mathrm{C}\right)$ RPMI 1640 medium at a density of $4 \times 10^{5}$ cells $/ \mathrm{ml}$. Cultures were allowed to equilibrate for $2 \mathrm{~h}$ at $37^{\circ} \mathrm{C}$ and $100 \mu \mathrm{l}$ of cell culture was added to each well of a 96-well plate. For the inhibition assay of $\mathrm{P} 1$ and P2, $6.25 \mathrm{nM}$ IFN- $\alpha \mathrm{B}$ was pre-incubated at $37^{\circ} \mathrm{C}$ for $1 \mathrm{~h}$ with varying concentrations $(0-250 \mu \mathrm{M})$ of the polypeptides. The mixtures were added to the Daudi cells and incubated at $37^{\circ} \mathrm{C}$ for 3 days. For the inhibition assay of polyclonal antibodies, serial dilutions $\left(10^{-1}-10^{-5}\right)$ of the polyclonal antibodies were pre-incubated with Daudi cells at $4^{\circ} \mathrm{C}$ for $1 \mathrm{~h}$, followed by the addition of $6.25 \mathrm{nM}$ IFN- $\alpha \mathrm{B}$ and incubation at $37^{\circ} \mathrm{C}$ for 3 days. Cell proliferation was determined by an MTT colorimetric assay (24). 
In vitro inhibition assay of antiviral activity of IFN- $\alpha$ B

Antiviral assays were performed using a combination of Hep 2/c cells and encephalomyocarditis virus (EMCV). Polypeptides (0$1,250 \mu \mathrm{M}$ ) were pre-incubated with $2.5 \mathrm{nM}$ IFN $-\alpha B$ at $37^{\circ} \mathrm{C}$ for $1 \sim 2 \mathrm{~h}$. The mixture was added to $100 \mu \mathrm{l}$ of Hep $2 / \mathrm{c}$ cells $\left(5 \times 10^{4}\right.$ cells/100 $\mu \mathrm{l} /$ well) on a 96 -well plate and incubated at $37^{\circ} \mathrm{C}$ for 1 day. Following incubation, $200 \mu \mathrm{l}$ of viral suspension was added to all wells and incubated at $37^{\circ} \mathrm{C}$ for $25 \sim 26$ h. The complete (100\%) cytopathic effect (CPE) of EMCV on unprotected virus was used as control. The CPE was determined by staining with amido blue black and absorbance measured at $620 \mathrm{~nm}$ in a Microelisa reader (25). For the inhibition assay of polyclonal antibodies, serial dilution and preincubation with Hep $2 / \mathrm{c}$ cells at $37^{\circ} \mathrm{C}$ for $2 \mathrm{~h}$ in a 96-well plate were performed. One IU/ $100 \mu \mathrm{l}(2.5 \mathrm{nM}) \mathrm{IFN}-\alpha \mathrm{B}$ was added to this mixture and incubated at $37^{\circ} \mathrm{C}$ for 1 day. Addition of the viral suspension and determination of the $\mathrm{CPE}$ were performed as mentioned above.

\section{Statistical analysis}

The non-parametric Spearman correlation test and Student $t$-test were used to detect differences as indicated in the Results section (26). The level of significance was

Figure 1 - Expression and purification of P1 (A) and P2 (B) by serial sonication steps and gel filtration chromatography. MW: Protein molecular weight marker; lane C: bacterial cell suspension before induction; lane 1: cell suspension after induction by IPTG; lanes 2, 4 and 6: supernatants of the 1st, 2nd and 3rd sonication; lanes 3, 5 and 7: pellets of the 1st, 2nd and 3rd sonication; lane 8: purified and refolded polypeptides (P1: $25 \mu \mathrm{g} /$ $\mathrm{ml}$; $2: 15 \mu \mathrm{g} / \mathrm{ml}$ ).
A

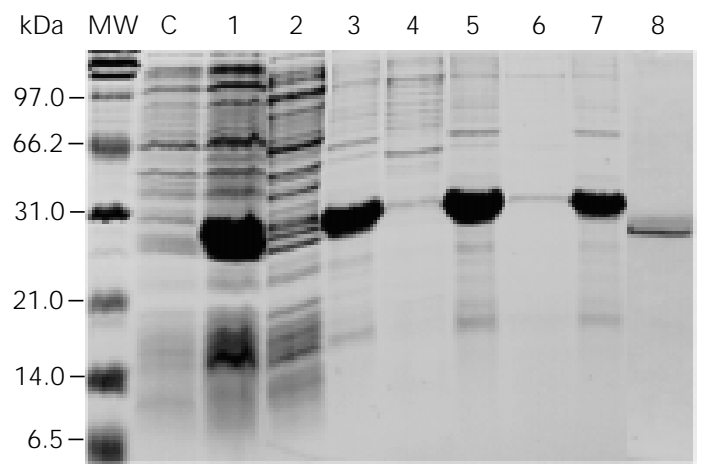

set at $\mathrm{P}<0.05$.

\section{Results}

\section{Expression and purification of polypeptides P1 and P2}

The cloned plasmids with the two cDNA fragments of the extracellular domain of IFNAR 1 were purified and cleaved with the restriction enzymes to check the presence of the inserted cDNA fragment. The high expression of polypeptides $\mathrm{P} 1(22 \mathrm{kDa})$ and P2 (17 kDa) in E. coli BL21(DE3)pLysS was demonstrated by SDS-PAGE under reducing conditions (Figure 1).

Polypeptides $\mathrm{P} 1$ and $\mathrm{P} 2$, produced as inclusion bodies in $E$. coli, were submitted to serial sonication steps for the isolation of recombinant polypeptides from bacterial proteins. As shown in Figure 1, the third sonication removed most, but not all, contaminant bacterial proteins. Sonication partially purified the polypeptides and facilitated the next purification step by gel filtration chromatography. The amount of purified and refolded polypeptides obtained by dialysis was $25 \mu \mathrm{g} /$ $\mathrm{ml}$ for $\mathrm{P} 1$ and $15 \mu \mathrm{g} / \mathrm{ml}$ for P2.

\section{Inhibition of the antiproliferative activity of IFN- $\alpha B$}

Based on the sensitivity of Daudi cells to IFN- $\alpha \mathrm{B}$ we initially used $25 \mathrm{nM}$ and 12.5

B

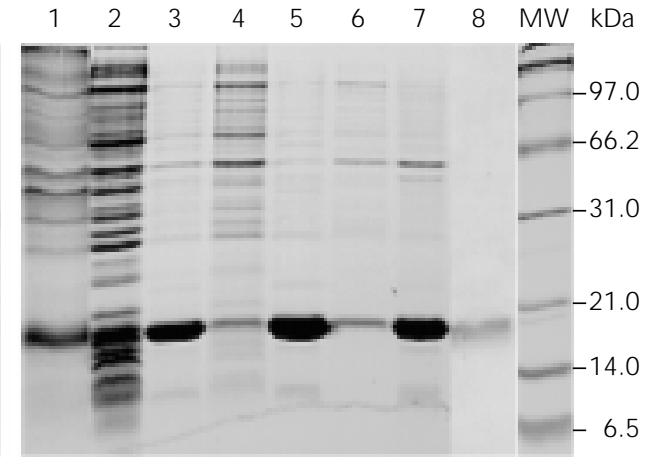


$\mathrm{nM}$ for the inhibition assay of the antiproliferative activity of this cytokine. Polypeptides $\mathrm{P} 1$ and $\mathrm{P} 2$ and their respective polyclonal antibodies did not inhibit IFN- $\alpha \mathrm{B}$ activity at these concentrations (data not shown). However, polypeptides P1 and P2 and their respective antibodies inhibited the antiproliferative activity of $6.25 \mathrm{nM}$ IFN$\alpha \mathrm{B}$. A significant inhibition of the antiproliferative activity of $6.25 \mathrm{nM}$ IFN- $\alpha \mathrm{B}$ was observed at $250 \mathrm{nM}, 2.5,25$ and $250 \mu \mathrm{M}$ P1 and at $250 \mu \mathrm{M}$ P2 (Student $t$-test, $\mathrm{P}<0.05$ ). This inhibition of IFN- $\alpha$ B activity was dosedependent (Spearman test: $\mathrm{r}=0.9856, \mathrm{P}=$ 0.0028 for $\mathrm{P} 1 ; \mathrm{r}=0.8857, \mathrm{P}=0.0333$ for $\mathrm{P} 2$ ). Anti-P1 antibodies inhibited the antiproliferative activity of IFN- $\alpha \mathrm{B}$ at dilutions of $10^{-3}$ and $10^{-1}$ and anti-P2 antibodies at dilutions of $10^{-3}, 10^{-2}$ and $10^{-1}$ (Student $t$-test, $\mathrm{P}<0.05$ ); this inhibition was also dose-dependent (Spearman test, $\mathrm{r}=1.0000, \mathrm{P}=0.0028$ for anti-P1 and anti-P2 antibodies) (Figure 2).

\section{Inhibition of the antiviral activity of IFN- $\alpha$ B}

IFN- $\alpha \mathrm{B}$ inhibited the CPE of Hep $2 / \mathrm{c}$ cells challenged with EMCV in a dose-dependent manner. The CPE of the virus was less than $10 \%$ with $125 \mathrm{nM}$ IFN- $\alpha \mathrm{B}$ (50 IU/ $100 \mu \mathrm{l})$ and $15-25 \%$ with $2.5 \mathrm{nM}(1 \mathrm{IU} / 100$ $\mu \mathrm{l})$ IFN- $\alpha \mathrm{B}$, showing the extremely high antiviral activity of IFN- $\alpha$ B on Hep $2 / \mathrm{c}$ cells challenged with EMCV.

As shown in Figure 3, there were no significant differences in CPE between controls and cells treated with the polypeptides. Polypeptides P1 and P2 inhibited the antiviral activity of $2.5 \mathrm{nM}$ IFN$\alpha \mathrm{B}$ by less than $3 \%$. The polyclonal anti$\mathrm{P} 1$ and anti-P2 antibodies did not block the antiviral activity of IFN- $\alpha \mathrm{B}$, showing the same CPE for IFN- $\alpha \mathrm{B}$ on control cells and cells treated with antibodies. The increased CPE at 0.1 antibody dilution observed at the same dilution of a negative serum may have been due to the interference of serum with IFN- $\alpha$ activity.

\section{Discussion}

Our main interest in the production of IFN- $\alpha$ inhibitors stems from the finding of the important role of IFN- $\alpha$ in the development of autoimmune diseases and GVHD. In this study, we have expressed two recombinant polypeptide fragments of the extracellular domain of IFNAR 1 in $E$. coli and their polyclonal antibodies in order to evaluate their in vitro inhibition activity on IFN- $\alpha$. The recombinant polypeptides $\mathrm{P} 1$ and $\mathrm{P} 2$ were expressed in the E. coli BL21(DE3) pLysS strain, using the pRSET expression plasmid vector, a pET derivative (plasmid for expression by $\underline{T} 7$ RNA polymerase)

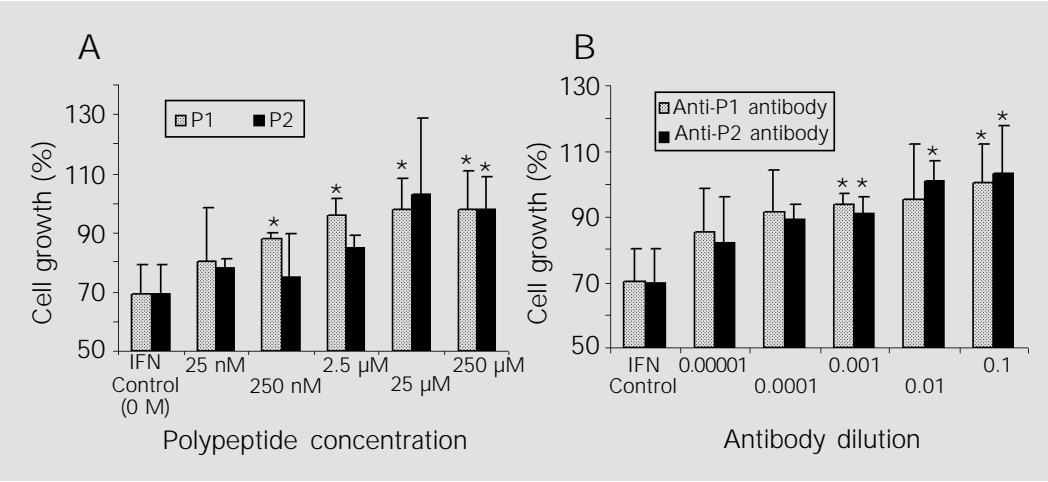

Figure 2 - Inhibition of antiproliferative activity of IFN- $\alpha$ B by polypeptide (A) or by polyclonal antibodies (B). Daudi cells $(4 \times 105 / \mathrm{ml})$ were incubated for 3 days with $25 \mathrm{nM} \sim 250 \mu \mathrm{M}$ polypeptides or serial dilutions of polyclonal antibodies in the presence of $6.25 \mathrm{nM}$ IFN- $\alpha \mathrm{B}$. Cell growth was determined by an MTT colorimetric assay $(595 \mathrm{~nm})$. $* \mathrm{P}<0.05$ for inhibition of IFN- $\alpha$ B activity compared to the IFN control (Student t-test).

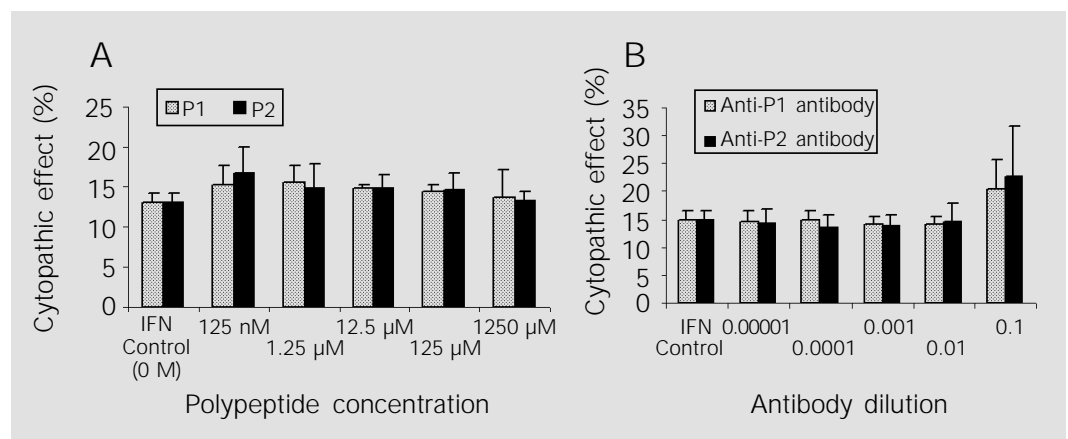

Figure 3 - Effect of polypeptides (A) and of their respective antibodies (B) on the antiviral activity of IFN- $\alpha$ B. Hep $2 / c$ cells $\left(3 \times 10^{5} / \mathrm{ml}\right)$ were incubated with $0.125 \sim 1250 \mu \mathrm{M}$ polypeptides or serial dilutions of polyclonal antibodies in the presence of $2.5 \mathrm{nM}$ IFN- $\alpha \mathrm{B}$ for 1 day before challenge with encephalomyocarditis virus. The cytopathic effect was determined by staining with amido blue black and absorbance reading at $620 \mathrm{~nm}$. 
which permits high levels of expression of heterologous gene products and easy purification of recombinant insoluble protein by centrifugation (27). The expression system BL21(DE3)pLysS/pRSET yielded a significant amount of polypeptides even when protein was lost during the purification process. The purification of the recombinant polypeptides involved three important steps: 1) isolation by serial sonication to separate the insoluble recombinant polypeptides from soluble bacterial proteins, 2) purification of the recombinant polypeptides by chromatography under denaturing conditions, and 3) refolding of the polypeptides by dialysis against decreasing concentrations of denaturant in order to gradually remove the denaturant. To avoid aggregation during dialysis, refolding experiments were performed with lower concentrations of the polypeptides $(<100 \mu \mathrm{g} / \mathrm{ml})$.

$\mathrm{P} 1$ and $\mathrm{P} 2$ inhibited $6.25 \mathrm{nM}$ IFN- $\alpha \mathrm{B}$ in a dose-dependent manner in the antiproliferative assays. P1 showed stronger inhibition than $\mathrm{P} 2$ at $250 \mathrm{nM}, 2.5 \mu \mathrm{M}$, and $25 \mu \mathrm{M}$. However, the polypeptides did not inhibit the antiproliferative activity of higher concentrations of IFN- $\alpha \mathrm{B}$ (12.5 and $25 \mathrm{nM}$ IFN$\alpha B$ ) (data not shown) although they were used at 10,000-fold molar excess over IFN$\alpha \mathrm{B}$.

It has been reported that the two subunits of IFN- $\alpha$ receptor, IFNAR 1 and IFNAR 2, participate in the binding of IFN- $\alpha$. The IFN$\alpha$ binding affinity for the receptor was increased by the co-expression of IFNAR 1 and IFNAR 2, which itself binds weakly to IFN- $\alpha$ (28-30). Therefore, the need of a high concentration of recombinant polypeptides for inhibition of IFN- $\alpha$ B activity and the absence of response to high concentrations of IFN- $\alpha \mathrm{B}$ in our experiments could be due to the lack of synergism of IFNAR 2 in the binding process. In other words, the natural IFNAR 1 on the surface of Daudi cells has more affinity for IFN- $\alpha$ because of the cooperative action of IFNAR 2 than the recombi- nant polypeptide. In our experiments, each inhibition test of the antiproliferative activity of IFN- $\alpha \mathrm{B}$ was carried out by incubation for 3 days at $37^{\circ} \mathrm{C}$. During this period, a reversible reaction of IFN- $\alpha$ B with recombinant polypeptides and natural IFNAR may occur. The higher affinity of IFN- $\alpha \mathrm{B}$ for natural IFNAR on cells probably allowed IFN- $\alpha \mathrm{B}$ to display the antiproliferative activity. Moreover, Raz et al. (31) have suggested the participation of a third factor (accessory elements) encoded by a gene located on chromosome $21 \mathrm{q} 22.2$ for full IFN- $\alpha$ receptor activity. Therefore, the absence of these factors in the assays could result in the low affinity of the recombinant polypeptides.

Although the two recombinant polypeptides showed low inhibitory activity on IFN$\alpha \mathrm{B}$ in our in vitro experiments, they open the possibility of practical antagonist production in the cytokine research area. In pathological processes associated with cytokine disorders, such as GVHD and autoimmune diseases, the production of a cytokine or antibody has been investigated for therapeutic purpose.

The polyclonal anti-P1 and anti-P2 antibodies inhibited $6.25 \mathrm{nM}$ IFN- $\alpha \mathrm{B}$ in a dosedependent manner in the antiproliferative assays. Anti-P1 and anti-P2 antibodies showed similar inhibition of IFN- $\alpha$ B activity (Figure 2), but did not block IFN- $\alpha \mathrm{B}$ activity at higher concentrations. These antibodies were able to bind IFNAR on the surface of Daudi cells competing with IFN$\alpha \mathrm{B}$ for receptor binding and proved to be useful in studies of IFNAR binding for the isolation of natural IFNAR and accessory components related to natural IFNAR on the cell surface.

In the inhibition assay of IFN- $\alpha$ B activity by an antiviral test, we used Hep $2 / \mathrm{c}$ cells and EMCV. This combination showed high sensitivity to the antiviral activity of IFN$\alpha \mathrm{B}$, being able to inhibit more than $80 \%$ of the viral activity at less than $6.25 \mathrm{nM}$ (1 IU/ $100 \mu \mathrm{l})$ IFN- $\alpha \mathrm{B}$. IFN- $\alpha \mathrm{B}(125 \mathrm{nM})$ inhibited 
Daudi cell proliferation by $80 \%$ (50 IU/100 $\mu \mathrm{l})$ and $80 \%$ of the viral CPE on Hep 2/c cells at only $6.25 \mathrm{nM}$, showing its powerful antiviral activity. For this reason, the standard procedure for the identification of neutralizing anti-IFN antibodies is the antiviral neutralization assay according to the recommendations of the WHO Expert Committee on Biological Standardization (32). Nevertheless, it has been shown that the antiproliferative assay is easy to perform, reproducible, and more sensitive than the antiviral neutralization assay for the detection of neutralizing IFN- $\alpha$ antibodies (33). In our experiments, the antiviral assay did not show good sensitivity for the inhibition assay of two recombinant polypeptides and their respective polyclonal antibodies. The blocking activity of the recombinant polypeptides and polyclonal antibodies in the antiviral assay was lower when compared with the antiproliferative assay. This difference in sensitivity between the antiproliferative test and the antiviral test may be due to the different cell lines used presenting different IFNAR and consequently different IFNAR affinity for antibodies or IFN- $\alpha \mathrm{B}$.

The possibility of new therapeutic approaches to autoimmune diseases and GVHD is very important. We have studied the production of IFN- $\alpha$ inhibitors. However, the two recombinant polypeptides showed a low ability to act as IFN- $\alpha$ inhibitors. In further studies, we will investigate the role of IFNAR 2 and their antibodies. The anti-IFNAR 1 and anti-IFNAR 2 antibodies may be used together to totally inhibit the activity of all IFN- $\alpha$ subclasses.

\section{Acknowledgments}

The authors gratefully acknowledge the support of IFN- $\alpha$ B in the person of Dr. David Gangemi. We also thank Dr. Kath C. Zoon and Dr. Consuelo Dias for providing Daudi cells and Hep 2/c cells.

\section{References}

1. Branca A (1988). Interferon receptors. In Vitro Cellular and Developmental Biology, 24: 155-165.

2. Grossberg SE, Taylor JL \& Kushnaryov VM (1989). Interferon receptors and their role in interferon action. Experientia, 45: 508-513.

3. Kontsek P (1994). Human type I interferons: structure and function. Acta Virologica, 38: 345-360.

4. Aguet M \& Blanchard B (1981). High affinity binding of ${ }^{125}$-labeled mouse interferon to a specific cell surface receptor. Virology, 115: 249-261.

5. Branca A \& Baglioni C (1981). Binding to human cells of [ $\left.{ }^{125} \mid\right]$-labeled alpha interferon produced in E. coli: evidence for different receptors for type I and II interferons. Nature, 294: 768-770.

6. Aguet M, Grobke M \& Dreiding P (1984). Various human interferon $\alpha$ subclasses cross-react with common receptors: their binding affinities correlate with their specific biological activities. Virology, 132: 211-216.
7. Flores L, Mariano TM \& Pestka S (1991). Human interferon omega $(\omega)$ binds to the $\alpha / \beta$ receptor. J ournal of Biological Chemistry, 266: 19875-19877.

8. Preble OT, Black RJ \& Friedman RM (1982). Systemic lupus enythematosus: presence in human serum of an unusual acid-labile leukocyte interferon. Science, 216: 429-431.

9. Huang X, Yuan J, Goddard A, Foulis A, J ames RFL, Lernmark A, Pujol-Borrell R, Rabinovitch A, Somoza N \& Stewart TA (1995). Interferon expression in the pancreases of patients with type I diabetes. Diabetes, 44: 658-664.

10. Abdi EA \& Venner PA (1986). Immune thrombocytopenia after alpha-interferon therapy in patients with cancer. J ournal of the American Medical Association, 255: 1878-1879.

11. Burman $P$, Totterman $\mathrm{TH}$, Oberg $\mathrm{K} \&$ Karlsson $F$ (1986). A thyroid autoimmunity in patients on long term therapy with leukocyte-derived interferon. J ournal of Clinical Endocrinology and Metabolism,
63: 1086-1090.

12. Fabris $P$, Betterle $C$, Floreani $A$, Greggio $N A$, De Lazzari F, Naccarato R \& Chiaramonte M (1992). Development of type I diabetes during interferon alpha therapy for chronic HCV hepatitis. Lancet, 340: 548.

13. Browett PJ, Nelson J, Tiwari S, Van de Water NS, May S \& Palmer SJ (1994). Graft-versus-host disease following interferon therapy for relapsed chronic myeloid leukemia post-allogeneic bone marrow transplantation. Bone Marrow Transplantation, 14: 641-644.

14. Klingemann HG, Grigg AP \& Wilkie-Boyd K (1991). Treatment with recombinant interferon $(\alpha-2 \beta)$ early after bone marrow transplantation in patients at high risk for relapse. Blood, 78: 3306-3311.

15. Reyes VE \& Klimpel GR (1987). Interferon alpha/beta synthesis during acute graftversus-host disease. Transplantation, 43: 412-416.

16. Pavord S, Sivakumaran M, Durrant $S \&$ Chapman C (1992). The role of alpha in- 
terferon in the pathogenesis of GVHD. Bone Marrow Transplantation, 10: 477.

17. Afifi MS, Kumar $\vee \&$ Bennett M (1985). Stimulation of genetic resistance to marrow grafts in mice by interferon $\alpha / \mathbb{B}$. J ournal of Immunology, 134: 37-39.

18. Heremans $H \&$ Billiau A (1989). The potential role of interferons and interferon antagonists in inflammatory disease. Drugs, 38: 957-972.

19. Uzé G, Lutfalla G, Eid P, Maury C, Banda MT, Gresser I \& Mogensen K (1991). Murine tumor cells expressing the gene for the human interferon $\alpha / \beta$ receptor elicit antibodies in syngeneic mice to the active form of the receptor. European J oumal of Immunology, 21: 447-451.

20. Benoit $P$, Maguire $D$, Plavec I, Kocher $H$, Tovey M \& Meyer F (1993). A monoclonal antibody to recombinant human IFN- $\alpha$ receptor inhibits biologic activity of several species of human IFN- $\alpha$, IFN- $\beta$ and IFN- $-\omega$. J ournal of Immunology, 150: 707-716.

21. Nguyen NY, Sackett D, Hirata RDC, Levy DE, Enterlene J C, Bekisz J B \& Hirata MH (1996). Isolation of a biologically active soluble human interferon- $\alpha$ receptor-GST fusion protein expressed in Escherichia coli. J ournal of Interferon and Cytokine Research, 16: 849-856.
22. Hirata $M H$, Sackett $D$, Hirata RDC \& Nguyen NY (1996). Human interferon- $\alpha$ receptor: Identification of the region involved in binding to interferon- $\alpha \mathrm{B}$. J ournal of Interferon and Cytokine Research, 16: 839-848.

23. Lowry $\mathrm{OH}$, Rosebrough NJ, Farr AL \& Randall RJ (1951). Protein measurement with folin phenol reagent. J ournal of Biological Chemistry, 193: 265-275.

24. Mosmann T (1983). Rapid colorimetric assay for cellular growth and survival: application to proliferation and cytotoxic assays. J oumal of Immunological Methods, 65: 55-63.

25. Meager A (1987). Quantification of interferons by anti-viral assays and their standardization. In: Clemens MJ , Morris AG \& Gearing AJ H (Editors), Lymphokines and Interferons: A Practical Approach. IRL Press, Oxford, England.

26. Rosner B (1986). Fundamentals of Biostatistics. 2nd edn. PWS, Boston.

27. Studier W, Rosemberg AH, Dunn JJ \& Dubendorff J W (1990). Use of T7 polymerase to direct expression of cloned genes. Methods in Enzymology, 185: 6089.

28. Domanski $P$, Witte $M$, Kellum $M$, Rubinstein $M$, Hackett R, Pitha P \& Colamonici
OR (1995). Cloning and expression of a long form of the $B$ subunit of the interferon $\alpha \beta$ receptor that is required for signaling. J oumal of Biological Chemistry, 270: 21606-21611.

29. Cohen B, Novick D, Barak $S \&$ Rubinstein M (1995). Ligand-induced association of the type I interferon receptor components. Molecular and Cellular Biology, 15: 4208-4214.

30. Cutrone EC \& Langer J A (1997). Contributions of cloned type I interferon receptor subunits to differential ligand binding. FEBS Letters, 404: 197-202.

31. Raz R, Cheung K, Ling L \& Levy DE (1995). Three distinct loci on human chromosome 21 contribute to interferon-alpha/beta responsiveness. Somatic Cell and Molecular Genetics, 21: 139-145.

32. WHO Expert Committee on Biological Standardization (1983). Standardization of interferons. WHO Technical Report Series, 687: 50.

33. Prümmer O, Streichan U, Heimpel $\mathrm{H} \&$ Porzsolt F (1994). Sensitive antiproliferative neutralization assay for the detection of neutralizing IFN- $\alpha$ and IFN- $\beta$ antibodies. J oumal of Immunological Methods, 171: 45-53. 